\title{
Public Financial Management, Accountability, and Citizens' Trust
}

\author{
Anto Bajo* \\ Marko Primorac * \\ Dario Runtic ${ }^{* * *}$
}

\author{
UDK : $\quad 336.132 .11:: 35.073 .52(497.5)$ \\ 35.086:351 / 353(497.5) \\ Preliminary scientific report / prethodno znanstveno priopćenje \\ Received/primljeno: 4.12.2016. \\ Accepted / prihvaćeno: 11.9.2017.
}

The main objective of the paper is to present opportunities for the application of analytical tools to improve the quality of financial management, as well as increase the level of accountability and citizens' trust in state and local government units. Moreover, the paper focuses on the Public Expenditure and Financial Accountability (PEFA) program as a framework for assessing and reporting on the strengths and weaknesses of public financial management (PFM). By 2015, 541 countries have applied PEFA, with

* Anto Bajo, PhD, associate professor at the Chair for Finances, Faculty of Economics and Business, University of Zagreb, Croatia / Institute of Public finance, Zagreb, Croatia (izvanredni professor na Katedri za financije Ekonomskog fakulteta Sveučilišta u Zagrebu / Institut za javne financije, e-mail: bajo@ijf.hr)

** Marko Primorac, PhD, assistant professor at the Chair for Finances, Faculty of Economics, University of Zagreb, Croatia (docent na Katedri za financije Ekonomskog fakulteta Sveučilišta u Zagrebu, e-mail: mprimorac@efzg.hr)

*** Dario Runtić, Association of Cities in the Republic of Croatia (Udruga gradova u Republici Hrvatskoj; e-mail: Dario@udruga-gradova.hr) 
294 publicly available summaries and scores. In Croatia, PEFA assessment has only been conducted at the subnational level, for four cities - Crikvenica, Koprivnica, Labin, and Sisak. The PEFA assessments conducted in Croatia proved to be extremely beneficial for identifying the main problems, as well as the factors supporting better performance and possible further action that needs to be taken to improve PFM in Croatian local government units.

Keywords: public financial management, PEFA, local government units, Croatia

\section{Introduction}

Over the last decade, Central, Eastern, and South-Eastern European countries have undergone significant public financial management (PFM) reforms. Budgetary systems in these countries have been significantly improved with the introduction of fiscal rules, medium-term budgetary frameworks, and program budgeting, while accounting systems have benefited from a gradual shift towards reporting according to international standards like the Government Finance Statistics (GFS) or the European System of Accounts (ESA). In addition, accounting systems have been acquiring accrual accounting and International Public Sector Accounting Standards (IPSAS), making reporting systems more comprehensive and transparent.

The financial crisis has seriously affected public finances in all the abovementioned countries, undermining the reforms implemented, and putting other, more advanced, reforms on hold. Moreover, further weaknesses in the public financial management systems of these countries have been exposed. These include poor quality of public sector data, inadequate public financial controls, inadequate management of fiscal risks, and inefficient public investments. To cope with these problems, current public financial management reforms are increasingly focusing on responsibility and accountability - through Public Internal Financial Controls (PIFC) and fiscal responsibility documents - as well as on improved risk management and greater transparency.

The main objective of the paper is to determine opportunities for the application of analytical tools to improve the quality of financial management, and increase the level of accountability and citizens' trust in state 
and local government units. Public expenditure and financial accountability (PEFA) is a useful analytical tool for the achievement of these goals. Since 2001 - when the PEFA initiative was created - 546 PEFA assessments have been performed worldwide, resulting in 300 publicly accessible reports. PEFA assessments have also been conducted in Croatia, but only at the subnational level. The assessments performed for four selected cities (Labin, Crikvenica, Koprivnica, and Sisak) confirm the justification of the use of PEFA to increase responsibility for the provision of public services and citizen trust in the administrative bodies of local government units.

The paper is divided into four parts. Following the introduction, the second part explains the purpose and intended use of analytical tools to support financial management in state and local government, and to increase their responsibility for providing public goods and services. The third part provides the key results of the PEFA assessment for four Croatian local government units, while the fourth part is the conclusion.

\section{Public Expenditure and Financial Accountability Framework}

PEFA was founded in 2001 as a multi-agency partnership program sponsored by the European Commission, the International Monetary Fund, the World Bank, the United Kingdom's Department for International Development, the French Ministry of Foreign Affairs, the Royal Norwegian Ministry of Foreign Affairs, the Swiss State Secretariat for Economic Affairs, and the SPA Strategic Partnership with Africa (Andrews, 2015). The standard framework for PFM diagnostics assessment was introduced in 2005, with upgrades in 2011 and 2016.

The PEFA program provides a framework for assessing and reporting on the strengths and weaknesses of PFM, using quantitative indicators to measure performance (PEFA Secretariat, 2016c). It is not only intended for monitoring purposes, but also for public finance management reform. It may be referred to as a global instrument, recognised as the gold standard to create strong and effective public financial management. Because PEFA is an evidence-based program, it is reliable and strongly influences internal decision-making within governments at both the national and subnational level. In the aftermath of the financial crisis, economies have tended to achieve greater financial transparency and reduce risks as much as possible. 
PEFA offers a common basis for examining PFM performance across national and subnational governments. In addition to governments, other users of PEFA include civil society organisations and international development institutions. PEFA scores and reports allow users to gain a quick overview of the strengths and weaknesses of a country's PFM system. It also reveals the implications of the overall results for the key goals of fiscal discipline, strategic resource allocation, and efficient service delivery. The PEFA analysis thereby contributes to dialogue regarding the need for and priorities in PFM reform (PEFA Secretariat, 2016).

PEFA may be defined as a methodology for estimating the performance of public finance management. It identifies 94 dimensions, analysed across 31 indicators in 7 pillars (budget reliability, transparency of public finances, management of assets and liabilities, policy-based fiscal strategy and budgeting, predictability and control in budget execution, accounting and reporting, and external scrutiny and audit).

Using quantitative indicators, PEFA aims to evaluate and assess PFM performance at particular points in time. It is built on several principles, including a country-led agenda, coordinated support from donors and international finance institutions, and a shared data pool on public finance management.

Some of the main goals of PEFA are strengthening the capacities to assess PFM through encouraging country ownership, reducing transaction costs, stimulating donor harmonisation, and monitoring progress of PFM over time. It was founded in 2001 to harmonise the different assessment and diagnostic tools that various organisations (donors) were using (Allen et al., 2004). In this regard, PEFA has many advantages over other PFM diagnostic frameworks in terms of comprehensiveness and a user-friendly approach (Andrews, 2007; De Renzio, 2013). However, it is also subject to criticism (see, for example, Dabla-Norris et al., 2010; Andrews et al., 2014). The main purpose of its establishment was to improve the effectiveness of fiscal policies and reduce the costs of multiple assessments. Effective PFM systems are of crucial importance for poverty reduction and stimulation of development policies. If PFM is done properly, it ensures that revenues are collected efficiently and used in a sustainable, effective, rational, and appropriate manner.

Generally, PEFA measures the magnitude of efficiency of PFM, processes, and institutions in achieving aggregate fiscal discipline, strategic allocation of resources, and efficient service delivery as the three main goals that have been outlined. The program is responsible for capturing changes in PFM practices and highlighting good practice among those it analyses. 


\subsection{PEFA Development}

The first publicly available version of PEFA was launched in 2005, and the first two countries analysed that year were Afghanistan and Zambia. Since its establishment in 2001, PEFA has recorded 40,000 performance scores and has been used more than 500 times across 150 countries. We can distinguish between four phases of the program: development (2002-2005), dissemination (2006-2008), integration (2009-2012), and global public $\operatorname{good}(2012-2017)$.

Diagram 1. PEFA life cycle

Source: Authors

The purpose of a good PFM system is to ensure that government policies are implemented as intended and achieve their objectives. An open and orderly PFM system is an enabling element needed for desirable fiscal and budgetary outcomes (PEFA Secretariat, 2016c):

- Aggregate fiscal discipline requires effective control of the total budget and the management of fiscal risks

- Strategic allocation of resources involves planning and executing the budget in line with government priorities aimed at achieving policy objectives

- Efficient service delivery requires using budgeted revenues to achieve the best levels of public services with the resources available

PEFA identifies seven pillars of performance in open and orderly PFM systems that are essential to achieving these objectives. The seven pillars thereby define the key elements of a PFM system. Each pillar comprises a group of indicators that capture the performance of the key systems, processes, and institutions of the government. Each indicator in turn includes one or more performance dimensions. Each dimension measures performance against a four-point ordinal scale from $A$ to $D$. The calibration of the dimensions is based on the presence of important attributes relevant to different standards of performance (PEFA Secretariat, 2016c). 
Table 1. PEFA's seven pillars

\begin{tabular}{|l|l|}
\hline Pillar & Objective \\
\hline Budget reliability & $\begin{array}{l}\text { The government budget is realistic and is implemented as intend- } \\
\text { ed. This is measured by comparing actual revenues and expendi- } \\
\text { tures (the immediate results of the PFM system) with the original } \\
\text { approved budget. }\end{array}$ \\
\hline $\begin{array}{l}\text { Transparency of } \\
\text { public finances }\end{array}$ & $\begin{array}{l}\text { Information on PFM is comprehensive, consistent, and acces- } \\
\text { sible to users. This is achieved through comprehensive budget } \\
\text { classification, transparency of all government revenue and ex- } \\
\text { penditure including intergovernmental transfers, published infor- } \\
\text { mation on service delivery performance, and ready access to fiscal } \\
\text { and budget documentation. }\end{array}$ \\
\hline $\begin{array}{l}\text { Management of } \\
\text { assets and liabilities }\end{array}$ & $\begin{array}{l}\text { Effective management of assets and liabilities ensures that pub- } \\
\text { lic investments provide value for money, assets are recorded and } \\
\text { managed, fiscal risks are identified, and debts and guarantees are } \\
\text { prudently planned, approved, and monitored. }\end{array}$ \\
\hline $\begin{array}{l}\text { Policy-based } \\
\text { fiscal strategy and } \\
\text { budgeting }\end{array}$ & $\begin{array}{l}\text { The fiscal strategy and the budget are prepared with due regard } \\
\text { to government fiscal policies, strategic plans, and adequate mac- } \\
\text { roeconomic and fiscal projections. }\end{array}$ \\
\hline $\begin{array}{l}\text { Predictability and } \\
\text { control in budget } \\
\text { execution }\end{array}$ & $\begin{array}{l}\text { The budget is implemented within a system of effective stand- } \\
\text { ards, processes, and internal controls, ensuring that resources are } \\
\text { obtained and used as intended. }\end{array}$ \\
\hline $\begin{array}{l}\text { Accounting and } \\
\text { reporting }\end{array}$ & $\begin{array}{l}\text { Accurate and reliable records are maintained, and information } \\
\text { is produced and disseminated at appropriate times to meet deci- } \\
\text { sion-making, management, and reporting needs. }\end{array}$ \\
\hline audit & $\begin{array}{l}\text { Public finances are independently reviewed and there is external } \\
\text { follow-up on the implementation of recommendations for im- } \\
\text { provement by the executive. }\end{array}$ \\
\hline
\end{tabular}

Source: Authors, based on PEFA methodology (PEFA Secretariat 2016, 2016a, 2016b and 2016c)

The highest score is warranted for an individual dimension if the core PFM element meets an internationally recognised standard of good performance. Dimension-specific scores are aggregated to reach an overall score for each indicator, using an appropriate method based on the degree of linkage between the individual dimensions (PEFA Secretariat, 2016c). PEFA 2016 is the latest upgrade since its inception in 2001. It uses the results of indicator calculation evidence to provide an estimation of the PFM system with respect to the seven pillars, and analyse whether it satisfies the previously mentioned desired outcome. The program supports sustainable development by updating new and improved benchmarks for 
evaluating PFM. Secondly, it introduces the seventh pillar that is focused on the detailed planning of public investments, assets, and liabilities. PEFA 2016 analyses both tax and non-tax revenues, which makes predictions even more precise. PEFA 2016 also emphasises transparency and openness by encouraging an increase in the availability of budget documentation, procurement, fiscal strategy, and risks. Last but not least, it implements a clearer and simpler scoring system than the previous version by substituting the 'not rated' code with a 'D' score, meaning that there is insufficient information or performance below a basic level.

The core PEFA methodology initially focused on central government, including related oversight and accountability institutions, such as the legislature and supreme audit institutions. However, PEFA has increasingly been used in the assessment of subnational government PFM performance (Audras \& Almanza, 2013). The scope of the category of 'central government', as used in PEFA, is based on the classification structure developed by the International Monetary Fund (IMF) for Government Finance Statistics (GFS). (PEFA Secretariat, 2016c)

PEFA influences the improvement of PFM in several ways. For instance, the results of the 2011 report show that dimensions which include a concentration of reform actors and strictly legal reform measures are improving much faster than those involving a large number of actors across government bodies and dimensions where compliance with laws or reform activities are necessary.

Besides, based on a review of several countries there is suitable evidence that PEFA assessments have made an impact on government even in relatively short periods. PEFA assessments have led to direct change in government PFM reform programs. It provides governments with a comprehensive view of both strengths and weaknesses in a single document, and provides an insight into achievements and challenges on the basis of evidence. This has led to the confirmation of good government policies and a definition of challenges that put pressure on government to persist with PFM reforms (Mackie \& Caprio, 2011).

The PEFA framework has provided an opportunity for the analysed countries to share their experience with other countries and thereby accelerate the development process. The most important factor is government participation, which has proved to be more important than the type of methodology used; for instance, whether the assessment was stand-alone or not, conducted as an external exercise and so on (Mackie \& Caprio, 2011). For example, in 2001-2006 the research conducted for heavily in- 
debted poor countries showed that a pattern of slow but steady improvements in PFM could be observed.

Countries implementing PEFA usually experience improvement in fiscal transparency. Moreover, the outcomes of certain reforms are determined more clearly. Some of the countries that have applied PEFA also highlight the emphasis on budget planning as one of the means by which PEFA influences PFM at both national and subnational levels. Another way in which the application of the program influences public finance management is a reduction in the number of government accounts (in the particular case of Nepal from 1,500 to 500, which is a result of the treasury management system reform applied after the PEFA assessment was conducted).

\section{Public Expenditure and Financial Accountability in the Republic of Croatia - Key Messages}

In 2014 the Croatian Association of Cities presented the main findings of the PEFA analysis for four pilot cities ${ }^{1}$ - common problems and recommendations for improving local government finance and broader prospects for the development of the management of public finance in Croatia. ${ }^{2}$ PEFA assessments were conducted only at the subnational level, for four cities - Crikvenica, Koprivnica, Labin, and Sisak. A number of positive features can be found as a result of public finance management in all four cities. Low scores are often the result of circumstances that cities cannot control. Some problems are common for all cities, and some specific to one or more cities.

\subsection{Problems Identified}

The PEFA assessment identified numerous problems hampering prudent public financial management in the cities. These include the unpredictability of revenues, limited coverage of financial reporting and audits,

1 Reports for Croatian LGUs were prepared by the PEFA assessment team for Local Government (LG) in Croatia, composed of three experts: the team leader (Giovanni Caprio), the senior PFM expert (John Wiggins), and a local PFM expert (Anto Bajo).

${ }^{2}$ PEFA results in Croatian are available at http://www.udruga-gradova.hr/pozivpredstavljanje-rezultata-pefa-projekta/ 
absence of an overview of fiscal risks posed by city-owned enterprises, absence of effective medium-term fiscal planning, high revenue arrears, absence of an internal audit, and non-application of International Public Sector Accounting Standards.

Unpredictability of revenues. In all four cities the unpredictability of revenues was found to be an obstacle to stable budgeting. Both main streams of revenue - the share of income tax receipts and the yield of utility and communal fees - are affected by this. The revenue from income tax may fall short of expectations because of adverse developments in the national economy, and because of specific adverse economic developments affecting the particular local government unit concerned. While the revenue from utility fees may be reasonably predictable, revenue from the community fees payable on new developments fluctuates very considerably in line with the pace of new development in each local government area, which, again, is affected by both the overall level of economic activity and specific local factors. Finally, revenue from the sale of assets, which may be an important source of funding for new investments, is also very difficult to predict.

Revenue in the form of specific grants from line ministries is also subject to uncertainty, in that decisions on such allocations appear to be taken on an ad hoc basis during the course of each financial year, depending on the overall availability of finance.

Revenues from small taxes decided locally, but collected for the most part by the Tax Administration - taxes on holiday homes, business names, consumption of beverages, and use of public space - are too small to be of much significance. While cities may be able to increase the yield of utility fees by drawing on all local sources of information to ensure that all chargeable properties are identified, they have no control over the collection of income and property transfer taxes, where they are entirely dependent on the Tax Administration which provides no information on payments made by individual taxpayers or on particular property transactions. Because of this, cities have to be ready to change their budgets during the course of each year, mainly by varying their expenditure on capital investment.

Limited coverage of financial reporting and audits. The focus of the cities' financial reporting seems to have been mainly on activities which are under direct control of the central administration, at least until the introduction of a single treasury account through which all revenue and expenditure passes. In a situation where budget users - schools, libraries, museums, and similar institutions - have retained separate bank accounts, reporting 
and audits cover only payments made to these institutions by the city and not their final expenditure. Budget users' own revenues (fees for nursery education, school meals, and so on) have been excluded from budgets, although they are covered by financial reports. Budget users have been subject to audit only occasionally, rather than every year as part of the audit of the city concerned.

Absence of overview of fiscal risks posed by city-owned enterprises. Important elements of the responsibilities of city governments (infrastructure maintenance, provision of utility services) are actually undertaken by enterprises established by city governments rather than by people directly employed by the cities. ${ }^{3}$ The very tight central control recently instituted over local government borrowing (including the provision of guarantees) has greatly reduced the potential risks of the operations of city-owned companies. No evidence was found of requests for subsidies by the cities concerned, but the cities would remain liable for the consequences of a breakdown in the services provided by the enterprises they own, as well as for the repayment of previous borrowing by these enterprises.

Absence of effective medium-term fiscal planning. It may be expected that public services will be delivered most efficiently if the resources and facilities required are planned over a period of several years. Investments can then be implemented economically, and staff and other resources needed for the on-going provision of services once new investments have been completed can be clearly identified. But in the current circumstances, the unpredictability of revenues makes such planning very difficult, if not impossible. A relatively higher proportion of city budgets is spent on capital expenditure than applies in the case of the central government: the consequence of revenue unpredictability is that budget adjustments tend to concentrate on capital programs where changes can be made without immediate disruption of services or of obligations to employees.

High revenue arrears. All four cities had substantial arrears of the revenues for which they are responsible. In part this is no doubt a reflection of the overall state of the Croatian economy, resulting in situations where debtors had no resources with which to meet their debts. This may also be a result of the concentration of city efforts on upgrading their IT systems, with fewer resources available to pursue unpaid utility and community fees.

${ }^{3}$ Such arrangements may also be important in allowing cities to avoid the constraints otherwise arising from the legal requirement not to spend more than 20 per cent of the annual budget on payroll costs. 
Absence of internal audit. Two of the four cities did not have a functioning internal audit at the time of our review. In one case we understand that the situation has subsequently been rectified. Given that resources are not available for the State Audit Office to carry out a full audit of every local government unit annually, it is particularly important that sufficient capacities for internal audits be available in every local government unit with a significant responsibility for the provision of public services.

Non-application of International Public Sector Accounting Standards. Current Croatian rules provide for expenditure to be reported on an accruals rather than a strictly cash basis. Thus although consistent standards are applied from year to year, financial reports conform neither to cash-based IPSAS nor to accruals-based standards, which would require full balance sheets and provision for the depreciation of assets.

\subsection{Factors Supporting Better Performance}

Several factors have been identified which support better performance. These are the establishment of single treasury accounts (STAs), establishment of strategic development plans, preparations for the use of EU funds, and a trend towards better management of city assets.

Establishment of single treasury accounts (STAs). The process of establishing single treasury accounts through which all of a city's revenues and expenditure will pass, including the expenditure and own revenues of budget users, ensures the completeness of budgeting and financial reporting. The process resolves the problems of incomplete reports of budget users' own revenues and final expenditures, and incomplete coverage of annual audits. It also tightens control over payrolls and all other expenditures. It is noted that the process has been completed in Crikvenica, Labin, and Sisak (apart from the Sports Centre) and Koprivnica.

Establishment of strategic development plans. All four cities recognise the need to improve medium-term budget planning, and to identify actions which will contribute to their growth and prosperity. Well-based and realistic strategic development plans offer the prospect of higher ratings. Labin and Koprivnica are somewhat ahead of the other two cities, but they also have work in progress in this area.

Preparations for the use of EU funds. The prospect of additional funds becoming available from the EU to finance investment and development expenditure gives a strong impetus to effective planning. But the EU funds 
will only be released when programs and projects to make effective use of those funds have been prepared and presented. Once the programs have been approved, EU funds will provide an important measure of assurance that infrastructure and other developments can actually be realised.

Trend towards better management of city assets. In the city of Sisak, the State Audit Office (SAO) has specifically recommended additional work to ensure that all the city's assets (housing, land, and other buildings) and other resources are fully identified and recorded, so that the city may ensure that they are properly safeguarded and maintained, as well as used to their best advantage. Thus the city of Labin shares its kindergarten facilities with neighbouring municipalities, and Koprivnica's fire service also serves the city's largest employer.

\subsection{Possible Further Action to Improve PFM}

It is also recognised that changes will take time to implement, and that significant new legislation is likely to be required for their implementation.

Change the arrangements for financing local government. Financing local government mainly through the allocation of shares of nationally collected income tax, paid by each local government unit's inhabitants, does not appear satisfactory. Local governments bear all the risks of revenue shortfalls, without any recourse to counteraction. There is no necessary connection between the yield of income tax and the needs of cities and other municipalities, and the yield of the tax - given the large tax-free allowances enjoyed by most taxpayers - is unlikely to be enough to support any significant further transfer of responsibilities from central to local government. It would be better for the central government to give grants to local government out of general taxation, which would be based on an assessment of the financing needs of each local government unit, taking into account its responsibilities for service provision and its own revenue-raising capacity. The grants would be based on a formula which would take into account population (including age distribution and relative sparsity) and revenue-raising capacity (based on a standard percentage applied to property values), with the objective of enabling at least a minimum level of each service to be provided throughout the country. Poorer local government units with lower revenue-raising capacity would receive relatively higher grants. The present arrangements whereby local governments can impose a surtax on the income tax payments of their inhabitants could be 
maintained, while they would also be at liberty to impose utility fees (or other local property taxes) at higher rates than assumed for the purposes of the grant calculations.

Develop an improved property tax. In addition to making funding from the central government more predictable, and better adapted to local government needs, action should be taken to enable local government units to increase receipts from the revenue streams they control. Cadastral records should be improved throughout the country, so that all local governments could impose an annual tax based in some way on property values. At the same time, restrictions on the way receipts of utility fees can be spent should be removed. Although tax on the sale of properties should probably remain a national tax, the Tax Administration should provide local governments with full information on transactions within their areas, so as to facilitate their revenue collection. Consideration should also be given to facilitating wider exchanges of information between the Tax Administration and local governments, so as to contribute to the full collection of the small taxes which the TA collects on behalf of most local governments, and perhaps also to assist the TA in identifying all those obligated to pay national taxes.

\subsection{Wider Perspectives for Local Government PFM}

The PEFA indicators look at whether governments are operating effectively, legally, and transparently. However, they do not really ask if services are being delivered efficiently, or if functions are optimally allocated to different levels of government. Zagreb aside, the average population of cities and municipalities in Croatia is not much more than 6,000. Counties have an average of 175,000 inhabitants, but they are responsible for only about 2.5 per cent of total general government expenditure, in comparison with cities and municipalities, which together account for some 8.5 per cent of general government expenditure.

In Croatia the scope for the devolution of responsibility for main public services - education, health, trunk roads - is limited by the size of local government units and their ability to finance and manage the functions in question. If consideration is to be given to the devolution of a greater number of responsibilities of the central government, then the overall structure of local government needs to be considered at the same time.

It should also be noted that there may be considerable economies of scale in avoiding the duplication of activities between neighbouring authorities. 
The question may also arise whether the central government has adequate powers to restrain unreasonable behaviour by particular local governments. There are apparently few restraints on the decision-making powers of elected mayors, concerning specific expenditure decisions and decisions on staff appointments. While there is no indication that problems of this kind are widespread, it may be considered whether there should be stronger protection for professional staff in local government who draw attention to the disadvantages of - wasteful or even illegal - actions and decisions insisted on by their political masters.

\section{Conclusion}

PEFA is a way of improving public financial management, it is also the key to improving fiscal performance. It ensures improvement in the provision of services such as education, public transportation, and health, and strongly enhances the reduction of poverty. Because PEFA makes PFM more transparent, citizens have better knowledge of how governments operate, so citizen satisfaction increases too. PEFA improves PFM, and subsequently improves the basis for investments and access to key public services. In essence, PEFA identifies the parts of PFM that need improvement and afterwards implements reforms and monitors the progress of PFM achieved by the application of a particular reform. To sum up, PEFA's results clearly show that its application is positively correlated with improvement in PFM.

In 2014, four local units in Croatia carried out a PEFA assessment. The results indicated the strengths and weaknesses in the financial management capacities of cities. The analysis identified areas for improvement within the competence of local government units, and some of the weaknesses arising from the current complex system of the organisation and financing of local government units upon which local units have no direct influence. With its four pilot studies, Croatia is the only EU member state that has conducted a PEFA assessment. This is not surprising given the fact that PEFA is intended mainly to improve PFM and to support the sustainable development of the economy, which indicates that the program benefits mostly developing countries. However, the Croatian experience might also be interesting for other countries - especially new EU member states - where PFM systems are still in the early phase of development. 


\section{References}

Allen, R., Schiavo-Campo, S., \& Garrity, T. C. (2004). Assessing and reforming public financial management: A new approach. Washington, DC: World Bank.

Andrews, M. (2015). Has Sweden injected realism into public financial management reforms in partner countries? (CID Working paper No. 303), Center for International Development at Harvard University. Retrieved from: [http://www. oecd.org/derec/sweden/Sweden-injected-realism-into-public-financial.pdf]

Andrews, M. (2007). What would an ideal public finance management system look like? In A. Shah (Ed.), Budgeting and budgetary institutions (pp. 359-383). Washington, DC: World Bank.

Andrews, M., Cangiano, M., Cole, N., de Renzio, P., Krause, \& P., Seligmann, R. (2014). This is PFM. Cambridge, MA: Center for International Development at Harvard University. Retrieved from: [https://bsc.cid.harvard.edu/files/bsc/ files/285_andrews_this_is_pfm.pdf]

Audras, F., \& Almanza, J.-F. (2013). PEFA methodology and sub-national governments: What lessons for AFD? Paris, France: Agence Française de Développement.

Dabla-Norris, E., Allen, R., Zanna, L.-F., Prakash, T., Kvintradze, E., Lledo, V., Yackovlev, I., \& Gollwitzer, S. (2010). Budget institutions and fiscal performance in low-income countries. Washington, DC: International Monetary Fund.

de Renzio, P. (2013). Assessing and comparing the quality of public financial management systems. In R. Allen, R. Hemming, \& B. H. Potter (Eds.), The international bandbook of public financial management (pp. 137-160). Basingstoke, United Kingdom: Palgrave Macmillan.

Mackie, A., \& Caprio, G. (2011). Assessing the impact of the PEFA Framework: A study for the PEFA steering committee (Main report: Volume I). Retrieved from: [http://siteresources.worldbank.org/PEFA/Resources/IIIb-AssessingtheImpactofPEFAFrameworkVolIFinalMay2011.pdf]

PEFA Secretariat (2014). Report on Public Expenditure and Financial Accountability (PEFA) - Performance report City of Crikvenica. Crikvenica: City of Crikvenica.

PEFA Secretariat (2014a). Report on Public Expenditure and Financial Accountability (PEFA) - Performance report City of Labin. Labin: City of Labin.

PEFA Secretariat (2014b). Report on Public Expenditure and Financial Accountability (PEFA) - Performance report City of Koprivnica. Koprivnica: City of Koprivnica

PEFA Secretariat (2014c). Report on Public Expenditure and Financial Accountability (PEFA) - Performance report City of Sisak. Sisak: City of Sisak.

PEFA Secretariat (2016). Handbook, volume I: The PEFA assessment process - planning, managing and using PEFA. Washington, DC: PEFA Secretariat.

PEFA Secretariat (2016a). Handbook, volume II: PEFA assessment fieldguide. Washington, DC: PEFA Secretariat.

PEFA Secretariat (2016b). Supplementary guidance for subnational PEFA assessments. Washington, DC: PEFA Secretariat.

PEFA Secretariat (2016c). Framework for assessing public financial management. Washington, DC: PEFA Secretariat. 


\section{PUBLIC FINANCIAL MANAGEMENT, ACCOUNTABILITY, AND CITIZENS' TRUST}

\section{Summary}

The main goal of the paper is to determine opportunities for the application of analytical tools to improve the management of state and local finances and increase the accountability and trust of citizens in state and local self-government units. PEFA is a useful tool for meeting such goals. PEFA is used on a global scale, primarily in countries that are beneficiaries of international aid, but also increasingly in countries that seek to increase their international credibility as well as their credibility regarding financial management in the eyes of their citizens. In the case of Croatia, PEFA was used in four cities in 2014. The implementation experience shows that PEFA allowed local government units to detect key weaknesses and technical shortcomings in their financial management, as well as to recognize the shortcomings of the provisions of certain regulations implemented at central government level. PEFA is an analytical tool that can be applied both at the national (central government) level and at the level of local self-government units. PEFA is certainly a demanding analytical tool which makes previous knowledge on financial management, budget accounting, and auditing more than desirable. For all European countries likely to join the European Union and finance part of their capital investments through EU funds, PEFA can be a very useful tool not only for the early recognition of weaknesses, but also strengths in financial management. Despite the fact that PEFA does not offer direct instructions on bow to solve potential problems in financial management, the findings of the analysis with the accompanying rankings are more than sufficient to serve as recommendations for addressing weaknesses in financial management. The implementation of PEFA requires strong support of the heads of local units and the state. These are also the people expected to initiate reforms and improve financial management. As an analytical tool, PEFA can belp these improvements happen much faster and more effectively.

Keywords: public financial management, PEFA, local government units, Croatia 


\title{
JAVNO FINANCIJSKO UPRAVALJANJE, ODGOVORNOST I POVJERENJE GRAĐANA
}

\begin{abstract}
Sažetak
Glavni je cilj rada utvrdit"i mogućnosti primjene analitičkib oruđa za poboljšanje upravljanja državnim i lokalnim financijama te povećanja odgovornosti $i$ povjerenja građana u državu i jedinice lokalne samouprave. PEFA je korisno orude za ispunjavanja takvih ciljeva. PEFA ima raširenu primjenu u svijetu, primarno u državama koje su korisnice medunarodnih pomoći, ali sve više i u državama koje nastoje povećati svoj međunarodni kredibilitet kao $i$ kredibilitet za financijsko upravljanje prema svojim građanima. PEFA se u slučaju Republike Hrvatske koristila na primjeru četiriju gradova u 2014. godini. Iskustva primjene pokazuju da su primjenom PEFA-e lokalne jedinice uspjele detektirati ključne slabosti $i$ tebničke nedostatke u financijskom upravljanju, ali $i$ prepoznati nedostatke odredbi pojedinib zakona i propisa koji su doneseni na razini središnje države. PEFA je analitičko orude koje se podjednako uspješno može primijeniti na razini država kao i na razini jedinica lokalne samouprave. Istina, PEFA je zabtjerno analitičko orude za čiju je primjenu potrebno imati prethodna znanja o financijskom upravljanju, računovodstvu proračuna i trgovačkih društva te reviziji. Za sve države u Europi koje teže pristupiti Europskoj uniji te dio svojih kapitalnih investicija financirati iz fondova EU-a, PEFA može biti dobro sredstvo $i$ orude za rano prepoznavanja slabosti, ali $i$ snaga $u$ njibovu financijskom upravljanju. Unatoč tome što PEFA ne nudi izravne prijedloge za rješavanja potencijalnih problema u financijskom upravljanju, nalazi iz provedene analize sa dodijeljenim rangovima $i$ više su nego dovoljni da posluže kao preporuke za otklanjanja slabosti u financijskom upravljanju. Za provedbu analiza PEFA potrebno je imati črrstu potporu čelnika lokalnih jedinica $i$ države. To su ujedno $i$ osobe od kojih se očekuje iniciranje reformi $i$ poboljšanja financijskog upravljanja. PEFA kao analitičko oruđe može pomoći da se ta poboljšanja ostvaruju znatno brže i kvalitetnije.

Ključne riječi: javno financijsko upravljanje, PEFA, jedinice lokalne samouprave, Hrvatska
\end{abstract}


